\title{
Effect of Dry-Salted Curcumin and Various Physicochemical and Technical Factors for the Shelf Life of White Shrimp (Litopenaeus vannamei)
}

\author{
NGUYEN PHUOC MINH ${ }^{1 *}$, NGUYEN HONG NGA², NGUYEN THANH THUY ${ }^{3}$, \\ and LONG GIANG BACH ${ }^{4}$
}
${ }^{1}$ Faculty of Chemical Engineering and Food Technology, Nguyen Tat Thanh University, Ho Chi Minh, Vietnam.
${ }^{2}$ Soc Trang Health Department, Soc Trang Province, Vietnam.
${ }^{3}$ Dong Thap University, Dong Thap Province, Vietnam.
${ }^{4} \mathrm{NTT}$ Hi-Tech Institute, Nguyen Tat Thanh University, Ho Chi Minh City, Vietnam.
${ }^{*}$ Corresponding author E-mail: ts.nguyenphuocminh@gmail.com
http://dx.doi.org/10.13005/ojc/340637

Received: November 08, 2018; Accepted: December 02, 2018)

\begin{abstract}
Loss of quality in seafood has been considered hazardous to consumers due to the proliferation and colonization of pathogenic bacteria. White shrimp (Litopenaeus vannamel) is a very important food due to high protein compostion and nutritional component. White shrimp (Litopenaeus vannamel) was a product of high value, for local consumption as well as export. However, the quick deterioration of white shrimp was caused owing to high moisture and protein content. Drying was one of the best choices to process this seafood. Besides the preservation purposes, the demand for dried shrimp has also been driven by the flavour of the products. Curcumin has been used in traditional remedy to prevent bacterial and fungal growth. It has been used as an ingredient in food recipes. Objective of this research focused on different technical aspects such as the effect of salt and curcumin concentration during soaking; temperature and time of steaming; temperature of drying to chemical, microbial and sensory characteristics during the processing of curcumin-dry-salted white shrimp. The present study also evaluated shelf life extension of curcumin-dry-salted white shrimp under storage conditions. It has been proved that this white shrimp was highly acceptable level in curcumin-dry-salted condition and also maintained best quality.
\end{abstract}

Keywords: White shrimp, Curcumin, Salting, Drying, Vacuum, Shelf-life.

\section{INTRODUCTION}

Shrimp represents one of the most vital commercial seafood in the world'. White shrimp (Litopenaeus vannamel) was one of the key species in Vietnamese shrimp farming. Vietnam's shrimp exports in 2017 recorded a remarkable growth with a growth of $22.3 \%$ compared with $6.7 \%$ in 2016 . According to the Vietnamese Directorate of Fisheries (D-Fish), the total output of shrimp in the country in 2017 reached 723.8 thousand metric tons (MT). Of that, brackish water shrimp output reached 683.4

This is an Open Access article licensed under a Creative Commons license: Attribution 4.0 International (CC- BY). Published by Oriental Scientific Publishing Company @ 2018

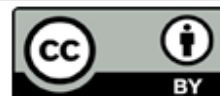


thousand MT including 256.4 thousand MT of black tiger shrimp and 427 thousand MT of white shrimp. The area of brackish water shrimp farming was 721.1 thousand ha, of which that for black tiger shrimp was 622.4 thousand ha and that for white shrimp was 98.7 thousand ha. Vietnamese farmers move away from farming black tiger shrimp (Penaeus monodon) and change to the white shrimp (Litopenaeus vannamel). Farmers in Vietnam, particularly in the Mekong Delta of the country are expanding white shrimp farming area. Exports of white shrimp occupied the largest proportion of $65.6 \%$; those of black tiger shrimp accounted for $23 \%$, the rest was marine shrimp with $11.6 \%$.

Regarding to nutritive characteristic of raised white leg shrimp Litopenaeus vannamei, it has good source of protein, carbohydrate, lipid, moisture and ash, calcium, sodium, potassium, manganese, copper, chromium ${ }^{2}$. Shrimps have low fat, less cholesterol and high polyunsaturated fatty acid (PUFA) content ${ }^{3}$.

There were several researches mentioned to white shrimp production. Product quality for drying of shrimp by microwave vacuum and air and freeze drying was compared ${ }^{4}$. The effect of drying media to characteristics of shrimp was studied ${ }^{5}$. The effects of different parameters on the drying kinetics and a lot quality characteristics of dried shrimp during drying by bed dryer were investigated ${ }^{6}$. The combine effect of salt and turmeric powder along with smoke-drying process on the production of high quality smoke-dried fish products from $G$. chapra, $X$. cancila, M. pancalus and their nutritive value was investigated ${ }^{7}$. The influence of various drying methods on physical and nutritional values of shrimp muscle was investigated ${ }^{8}$. The effect of turmeric on shelf life extension of shrimp Penaeus semisulcatus under chilled storage conditions was evaluated ${ }^{9}$. The effect of spices and herb for maintaining microbiological quality and stability of dried oil sardine fish during preservation under ambient temperature was studied ${ }^{10}$. The dried shrimp was produced by mixing with turmeric and salt under spouted bed technique ${ }^{11}$. Nutrition and stability of dry smoked and gamma irradiated shrimps were studied $^{12}$. The effect of steaming on physical and chemical parameters of white shrimp (Litopenaeus vannamel) was determined ${ }^{13}$.

The rate of deterioration in shrimp is highly temperature dependent and inhibited by reducing the storage temperature ${ }^{14}$. Several drying techniques such as freeze-drying ${ }^{15}$, superheated steam drying ${ }^{5}$, jet-spouted bed drying ${ }^{16}$, and heat pump drying ${ }^{17}$ have been applied to process shrimps. Traditional solar drying and hot air drying are still the most common approaches of shrimp processing. Sun drying is one of the most important low cost methods of shrimp preservation. However, blow flies caused heavy infestation of unsalted dried shrimp. Curcumin has been used in traditional remedy to prevent bacterial and fungal growth. It has been used as an ingredient in food recipes. It's a potential source of new herb to combat a variety of ailments as the species contain molecules credited with antiinflammatory, hypocholestraemic, choleratic, antirheumatic, insect repellent, antimicrobial, antifibrotic, antivenom, antidiabetic, antihepatotoxic as well as it can be used against cancer ${ }^{18}$. Objective of this research focused on different technical aspects such as the effect of salt, curcumin concentration during soaking; time of soaking; temperature of drying to chemical, microbial and sensory characteristics during the processing of curcumin-dry-salted white shrimp. The present study also evaluated shelf life extension of curcumin-drysalted white shrimp under storage conditions.

\section{MATERIALS AND METHOD}

\section{Material}

We collected white shrimp (Litopenaeus vannamei) from Vinh Chau district, Soc Trang province, Vietnam. They must be reared following VietGAP to ensure food safety. After collecting, they must be temporarily preserved by flake ice and conveyed to laboratory within $4 \mathrm{~h}$ for experiments. They were washed and sanitized under washing tank having 25 ppm chlorine with a support of air bubble blowing to remove foreign matters. Besides Litopenaeus vannamei we also used another material during the research such as chlorine, salt, curcumin, poly amid (PA) bag. Lab utensils and equipments included digital weight balance, Rotronic, stomacher, incubator, colony counter, vacuum sealing machine, steaming and dry oven.

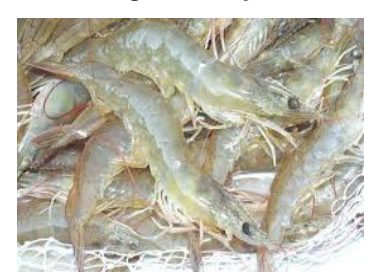

(a)

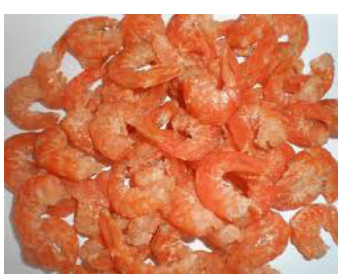

(b)
Fig. 1. (a) White shrimp (Litopenaeus vannamel), (b) dried shrimp 
Researching procedure

Effect of salting concentration to physicochemical, microbiological and sensory characteristics of the dry-salted white shrimp (Litopenaeus vannamei)

White shrimps (Litopenaeus vannamei) were treated with salt at different ratio $(0 \%, 0.25 \%$, $0.50 \%, 0.75 \%$ and $1.0 \%$ ) soaking $15 \mathrm{~min}$ to create a pleasant taste of dried product. All samples will then be dried by heat pump dryer at $55^{\circ} \mathrm{C}$ in 4 hours. Five dry-salted white shrimps were chosen randomly to analyse crude protein (\%), water activity (aw), total plate count (TPC, cfu/g) and sensory score.

Effect of curcumin addition to physicochemical, microbiological and sensory characteristics of the curcumin-dry-salted white shrimp (Litopenaeus vannamei)

White shrimps (Litopenaeus vannameI) after being treated with salt were treated with curcumin at different ratios $(0 \%, 0.25 \%, 0.5 \%$, $0.75 \%, 1.0 \%$ ) soaking $15 \mathrm{~min}$ to create a pleasant taste of dried product. All samples will then be dried by heat pump dryer at $55^{\circ} \mathrm{C}$ in 4 hours. Five dry-salted white shrimps were chosen randomly to analyse crude protein (\%), water activity (aw), TPC (cfu/g) and sensory score.

Effect of steaming temperature and time to physicochemical, microbiological and sensory characteristics of the curcumin-dry-salted white shrimp (Litopenaeus vannamei)

White shrimps (Litopenaeus vannamei) after being treated with salt and curcumin were steamed at different conditions $\left(100^{\circ} \mathrm{C}, 60 \mathrm{sec}\right.$.; $105^{\circ} \mathrm{C}, 45 \mathrm{sec} . ; 110^{\circ} \mathrm{C}, 30 \mathrm{sec}$. and $115^{\circ} \mathrm{C}, 15 \mathrm{sec}$. All samples will then be dried by heat pump dryer at $55^{\circ} \mathrm{C}$ in 4 hours. Five dry-salted white shrimps were chosen randomly to analyse crude protein (\%), water activity (aw), TPC (cfu/g) and sensory score.

Effect of drying temperature and time to physicochemical, microbiological and sensory characteristics of the curcumin-dry-salted white shrimp (Litopenaeus vannamei)

White shrimps (Litopenaeus vannamei) after being treated with salt, curcumin and steamed were dried by heat pump dryer in different conditions $\left(35^{\circ} \mathrm{C}, 6 \mathrm{~h} ; 40^{\circ} \mathrm{C}, 5.5 \mathrm{~h} ; 45^{\circ} \mathrm{C}, 5.0 \mathrm{~h} ; 50^{\circ} \mathrm{C}, 4.5 \mathrm{~h}\right.$; and $55^{\circ} \mathrm{C}, 4$ hours). Five curcumin-dry-salted white shrimps were chosen randomly to analyse crude protein (\%), water activity (aw), TPC (cfu/g) and sensory score.

Shelf-life of the curcumin-dry-salted white shrimp (Litopenaeus vannamei) during storage

Curcumin-dry-salted white shrimp (Litopenaeus vannamel) products were kept in two different packing (zipper top, vaccum) ways in PA bag and two different temperature storage conditions $\left(4 \pm 2^{\circ} \mathrm{C}, 28 \pm 2^{\circ} \mathrm{C}\right)$. Sensory score was evaluated in 3 months interval for 12 months.

Physico-chemical, microbial and sensory analysis Crude protein amount in the white shrimp samples was determined ${ }^{19}$. Water activity (aw) was measured by Rotronic instrument. TPC (cfu/g) was analysed by 3M-Petrifilm. Sensory score of Litopenaeus vannamei was assessed by a group of panelist using the 9-point hedonic scale.

\section{Statistical analysis}

The experiments were performed in triplicate. Statistical analysis was conducted by the Statgraphics Centurion XVI.

\section{RESULT \& DISCUSSION}

Effect of salting concentration to physicochemical, microbiological and sensory characteristics of the dry-salted white shrimp (Litopenaeus vannamei)

The raw shrimp was composed of nearly $80 \%$ of water. This figure was reported with black tiger shrimp and white shrimp ${ }^{20}$. White shrimps (Litopenaeus vannamel) were treated with salt at different ratio $(0 \%, 0.25 \%, 0.50 \%, 0.75 \%$ and $1.0 \%)$ soaking $15 \mathrm{~min}$ to create a pleasant taste of dried product. All samples will then be dried by heat pump dryer at $55^{\circ} \mathrm{C}$ in 4 hours. Five dry-salted white shrimps were chosen randomly to analyse crude protein (\%), water activity (aw), TPC (cfu/g) and sensory score. Results from Table 1. Showed that white shrimps (Litopenaeus vannamel) should be soaked with $0.75 \%$ salt in $15 \mathrm{~min}$ to get a pleasant taste.

In another study, the best quality dried shrimp was noted by two different groups: group one (salting 5\% with whole shrimp and then cooking for $20 \mathrm{~min}$, drying at $7^{\circ} \mathrm{C}$ for $2 \mathrm{~h}$ ), group two (peeling and treating under the same conditions as group one only for 10 minutes) $)^{21}$. 
Table 1: Effect of salting concentration to physicochemical, microbiological and sensory characteristics of the dry-salted white shrimp (Litopenaeus vannamei)

\begin{tabular}{ccccc}
\hline Salting concentration & Crude protein $(\%)$ & Water activity $\left(\mathrm{a}_{\mathrm{w}}\right)$ & TPC $(\mathrm{cfu} / \mathrm{g})$ & Sensory score \\
\hline $0 \%$ & $35.38 \pm 0.01^{\mathrm{c}}$ & $0.74 \pm 0.03^{\mathrm{a}}$ & $4.9 \times 102 \pm 0.02^{\mathrm{a}}$ & $5.11 \pm 0.03^{\mathrm{c}}$ \\
$0.25 \%$ & $36.01 \pm 0.02^{\mathrm{bc}}$ & $0.72 \pm 0.00^{\mathrm{ab}}$ & $4.1 \times 102 \pm 0.01^{\mathrm{ab}}$ & $6.09 \pm 0.03^{\mathrm{bc}}$ \\
$0.50 \%$ & $36.12 \pm 0.02^{\mathrm{ab}}$ & $0.78 \pm 0.03^{\mathrm{b}}$ & $3.1 \times 102 \pm 0.03^{\mathrm{b}}$ & $6.76 \pm 0.02^{\mathrm{b}}$ \\
$0.75 \%$ & $36.75 \pm 0.04^{\mathrm{b}}$ & $0.66 \pm 0.00^{\mathrm{bc}}$ & $2.5 \times 102 \pm 0.00^{\mathrm{bc}}$ & $6.94 \pm 0.04^{\mathrm{ab}}$ \\
$1.0 \%$ & $37.21 \pm 0.01^{\mathrm{a}}$ & $0.65 \pm 0.02^{\mathrm{c}}$ & $2.4 \times 102 \pm 0.01^{\mathrm{c}}$ & $7.09 \pm 0.01^{\mathrm{a}}$ \\
\hline
\end{tabular}

Note: the values were expressed as the mean of three repetitions; the same characters (denoted above), the difference between them was not significant $(\alpha=5 \%)$.

Effect of curcumin addition to physicochemical, microbiological and sensory characteristics of the curcumin-dry-salted white shrimp (Litopenaeus vannamei)

In tropical climate and under humid condition, heavy infestation of salted dried white shrimp was caused by blow fly and beetle larvae. To avoid such infestation and microbial contamination, salt and salt-curcumin were used combined in order to achieve the desire product. White shrimps (Litopenaeus vannamei) after being treated with salt were treated with curcumin at different ratios $(0 \%, 0.25 \%, 0.5 \%, 0.75 \%, 1.0 \%)$ soaking $15 \mathrm{~min}$ to create a pleasant taste of dried product. All samples will then be dried by heat pump dryer at $55^{\circ} \mathrm{C}$ in 4 hours. Five dry-salted white shrimps were chosen randomly to analyse crude protein (\%), water activity (aw), TPC (cfu/g) and sensory score. From table 2, the appropriate curcumin concentration should be used at $0.5 \%$ to get the highest crude protein content (\%), lowest water activity (aw), lowest microorganism (TPC, $\mathrm{cfu} / \mathrm{g}$ ) while having the highest sensory score.

Table 2: Effect of curcumin addition to physicochemical, microbiological and sensory characteristics of the curcumin-dry-salted white shrimp (Litopenaeus vannamei)

\begin{tabular}{ccccc}
\hline Curcumin & Crude protein $(\%)$ & Water activity $\left(\mathrm{a}_{\mathrm{w}}\right)$ & TPC $(\mathrm{cfu} / \mathrm{g})$ & Sensory score \\
\hline $0 \%$ & $36.75 \pm 0.04^{\mathrm{ab}}$ & $0.66 \pm 0.00^{\mathrm{a}}$ & $2.5 \times 102 \pm 0.00^{\mathrm{a}}$ & $6.94 \pm 0.04^{\mathrm{b}}$ \\
$0.25 \%$ & $36.82 \pm 0.02^{\mathrm{ab}}$ & $0.66 \pm 0.03^{\mathrm{a}}$ & $2.0 \times 102 \pm 0.01^{\mathrm{ab}}$ & $7.11 \pm 0.01^{\mathrm{b}}$ \\
$0.50 \%$ & $36.90 \pm 0.02^{\mathrm{ab}}$ & $0.65 \pm 0.02^{\mathrm{ab}}$ & $1.2 \times 101 \pm 0.03^{\mathrm{b}}$ & $8.64 \pm 0.03^{\mathrm{a}}$ \\
$0.75 \%$ & $36.96 \pm 0.00^{\mathrm{a}}$ & $0.64 \pm 0.01^{\mathrm{ab}}$ & $1.1 \times 101 \pm 0.02^{\mathrm{bc}}$ & $6.34 \pm 0.02^{\mathrm{bc}}$ \\
$1.0 \%$ & $37.03 \pm 0.0^{\mathrm{a}}$ & $0.63 \pm 0.04^{\mathrm{b}}$ & $1.0 \times 101 \pm 0.01^{\mathrm{c}}$ & $6.08 \pm 0.02^{\mathrm{c}}$ \\
\hline
\end{tabular}

Note: the values were expressed as the mean of three repetitions; the same characters (denoted above), the difference between them was not significant $(\alpha=5 \%)$.

The influence of temperature on convective drying of cooked shrimp was studied. Salting at $5 \%$ level followed by cooking for 20 min and drying for $2 \mathrm{~h}$ at $70^{\circ} \mathrm{C}$ was appropriate ${ }^{21}$. The synergistic effect of salt and turmeric powder along with smokedrying process on the production of high quality smoke-dried fish products from G. chapra, X. cancila, $M$. pancalus and their nutritive value was evaluated. The data has proved with strong evidence that Salt-turmeric treated smoke-dried three experimental fishes are rich in most of the nutrients essential for proper health maintenance of humans ${ }^{7}$.

Effect of steaming temperature and time to physicochemical, microbiological and sensory characteristics of the curcumin-dry-salted white shrimp (Litopenaeus vannamei)

White shrimps (Litopenaeus vannameI) after being treated with salt and curcumin were steamed at different conditions $\left(100^{\circ} \mathrm{C}, 60 \mathrm{sec}\right.$.; $105^{\circ} \mathrm{C}, 45$ sec.; $110^{\circ} \mathrm{C}, 30$ sec. and $115^{\circ} \mathrm{C}$, 15 seconds). All samples will then be dried by heat pump dryer at $55^{\circ} \mathrm{C}$ in 4 hours. Five dry-salted white shrimps were chosen randomly to analyse crude protein (\%), water activity (aw), TPC (cfu/g) and sensory score. Results from Table 1. Showed that white shrimps (Litopenaeus vannamel) should be steamed at $110^{\circ} \mathrm{C}$ in $30 \mathrm{sec}$. to get the highest quality of curcumindry-salted white shrimp (Litopenaeus vannamel).

The shrimpdrying processusingasuperheated steam drying cabinet within the temperature range 
of $140-160^{\circ} \mathrm{C}$ was performed ${ }^{22}$. The effect of steaming on physical and chemical characteristics white shrimp (Litopenaeus vannamei) was determined ${ }^{13}$.

Table 3: Effect of steaming temperature and time to physicochemical, microbiological and sensory characteristics of the curcumin-dry-salted white shrimp (Litopenaeus vannamei)

\begin{tabular}{lcccc}
\hline Steaming & Crude protein $(\%)$ & Water activity $\left(a_{w}\right)$ & TPC $(c f u / g)$ & Sensory score \\
\hline $100^{\circ} \mathrm{C}, 60 \mathrm{sec}$. & $36.90 \pm 0.02^{\mathrm{a}}$ & $0.65 \pm 0.02^{\mathrm{a}}$ & $1.2 \times 101 \pm 0.03^{\mathrm{a}}$ & $8.64 \pm 0.03^{\mathrm{ab}}$ \\
$105^{\circ} \mathrm{C}, 45 \mathrm{sec}$. & $36.22 \pm 0.01^{\mathrm{ab}}$ & $0.64 \pm 0.01^{\mathrm{ab}}$ & $0.8 \times 101 \pm 0.01^{\mathrm{ab}}$ & $8.69 \pm 0.02^{\mathrm{ab}}$ \\
$110^{\circ} \mathrm{C}, 30 \mathrm{sec}$. & $36.04 \pm 0.04^{\mathrm{b}}$ & $0.62 \pm 0.04^{\mathrm{ab}}$ & $0.4 \times 101 \pm 0.01^{\mathrm{b}}$ & $8.85 \pm 0.02^{\mathrm{a}}$ \\
$115^{\circ} \mathrm{C}, 15 \mathrm{sec}$. & $35.74 \pm 0.02^{\mathrm{c}}$ & $0.60 \pm 0.03^{\mathrm{b}}$ & $0.3 \times 101 \pm 0.00^{\mathrm{b}}$ & $8.21 \pm 0.00^{\mathrm{b}}$ \\
\hline
\end{tabular}

Note: the values were expressed as the mean of three repetitions; the same characters (denoted above), the difference between them was not significant $(\alpha=$

Effect of drying temperature and time to physicochemical, microbiological and sensory characteristics of the curcumin-dry-salted white shrimp (Litopenaeus vannamei)

Shrimp is a perishable product under hot and tropical regions. Drying is one of the efficient methods for food storage. Salting and drying are traditional ways to improve fish stability during storage. Besides the preservation purposes, the demand for dried fish has also been driven by the flavour of the products ${ }^{23}$.
White shrimps (Litopenaeus vannamei) after being treated with salt, curcumin and steamed were dried by heat pump dryer in different conditions $\left(35^{\circ} \mathrm{C}, 6 \mathrm{~h} ; 40^{\circ} \mathrm{C}, 5.5 \mathrm{~h} ; 45^{\circ} \mathrm{C}, 5.0 \mathrm{~h} ; 50^{\circ} \mathrm{C}, 4.5 \mathrm{~h}\right.$; and $55^{\circ} \mathrm{C}, 4$ hours). Five curcumin-dry-salted white shrimps were chosen randomly to analyse crude protein (\%), water activity (aw), TPC (cfu/g) and sensory score. Results from Table 4 . Showed that the drying process should be conducted at $50^{\circ} \mathrm{C}$ in $4.5 \mathrm{~h}$ to get the highest crude protein content (\%), lowest water activity $\left(\mathrm{a}_{\mathrm{w}}\right)$, lowest microorganism (TPC, cfu/g) while having the highest sensory score.

Table 4: Effect of drying temperature and time to physicochemical, microbiological and sensory characteristics of the curcumin-dry-salted white shrimp (Litopenaeus vannamei)

\begin{tabular}{ccccc}
\hline Drying condition & Crude protein $(\%)$ & Water activity $\left(\mathrm{a}_{\mathrm{w}}\right)$ & TPC $(\mathrm{cfu} / \mathrm{g})$ & Sensory score \\
\hline $35^{\circ} \mathrm{C}, 6 \mathrm{~h}$ & $34.98 \pm 0.01^{\mathrm{c}}$ & $0.70 \pm 0.03^{\mathrm{a}}$ & $1.2 \times 101 \pm 0.00^{\mathrm{a}}$ & $6.80 \pm 0.01^{\mathrm{c}}$ \\
$40^{\circ} \mathrm{C}, 5.5 \mathrm{~h}$ & $35.01 \pm 0.02^{\mathrm{bc}}$ & $0.69 \pm 0.01^{\mathrm{ab}}$ & $1.1 \times 101 \pm 0.04^{\mathrm{ab}}$ & $7.13 \pm 0.03^{\mathrm{bc}}$ \\
$45^{\circ} \mathrm{C}, 5.0 \mathrm{~h}$ & $35.19 \pm 0.00^{\mathrm{b}}$ & $0.68 \pm 0.01^{\mathrm{ab}}$ & $0.9 \times 101 \pm 0.01^{\mathrm{b}}$ & $7.66 \pm 0.02^{\mathrm{b}}$ \\
$50^{\circ} \mathrm{C}, 4.5 \mathrm{~h}$ & $35.26 \pm 0.01^{\mathrm{ab}}$ & $0.65 \pm 0.02^{\mathrm{b}}$ & $0.4 \times 101 \pm 0.03^{\mathrm{c}}$ & $8.90 \pm 0.00^{\mathrm{a}}$ \\
$55^{\circ} \mathrm{C}, 4.0 \mathrm{~h}$ & $36.04 \pm 0.04^{\mathrm{a}}$ & $0.62 \pm 0.04^{\mathrm{c}}$ & $0.4 \times 101 \pm 0.01^{\mathrm{c}}$ & $8.85 \pm 0.02^{\mathrm{a}}$ \\
\hline
\end{tabular}

Note: the values were expressed as the mean of three repetitions; the same characters (denoted above), the difference between them was not significant $(\alpha=5 \%)$.

Quality of dried shrimp performed by microwave vacuum and air and freeze drying was compared. They reported that the shrimp dried by the superheated steam had a higher degree of shrimp quality ${ }^{4}$. Drying of shrimp at hybrid superheated steam and heat pump dryers and reported the same characteristic in shrimp drying was studied ${ }^{24}$. The effects of different parameters on the drying and quality characteristics of dried shrimp under jet-spouted bed dryer were investigated ${ }^{6}$. The influence of drying conditions upon the quality of shrimp has been investigated ${ }^{25}$. Dehydration property of shrimp undergoing heat-pump drying process was investigated ${ }^{26}$. The influence of different drying methods on physical and nutritional characteristics of shrimp muscle was investigated. Different drying ways affected the physical and nutritional quality of shrimp muscle ${ }^{8}$. The dried shrimp was produced by mixing with turmeric and salt under spouted bed technique. The air drying chamber and hot air velocity were noted at $180^{\circ} \mathrm{C}$, $4.5 \mathrm{~m} / \mathrm{s}$ respectively ${ }^{11}$.

Shelf-life of the curcumin-dry-salted white shrimp (Litopenaeus vannamei) during storage Curcumin-dry-salted white shrimp 
(Litopenaeus vannamei) products were kept in two different packing (zipper top, vaccum) ways in PA bag and two different temperature storage conditions $\left(4 \pm 2^{\circ} \mathrm{C}, 28 \pm 2^{\circ} \mathrm{C}\right)$. Sensory score was evaluated in
3 months interval for 12 months. Results from Table 5 showed that the curcumin-dry-salted white shrimp (Litopenaeus vannameI) still mainted quality during 12 months of storage.

Table 5: Shelf-life (sensory score) of the curcumin-dry-salted white shrimp (Litopenaeus vannamei) during storage

\begin{tabular}{|c|c|c|c|c|}
\hline \multirow[t]{2}{*}{$\begin{array}{l}\text { Storage time } \\
\text { (month) }\end{array}$} & \multicolumn{2}{|c|}{$\begin{array}{l}\text { Curcumin-dry-salted white shrimp } \\
\text { (Litopenaeus vannamei) by the storage } \\
\text { temperature }\left({ }^{\circ} \mathrm{C}\right) \text { kept in PA (zipper top) }\end{array}$} & \multicolumn{2}{|c|}{$\begin{array}{l}\text { Curcumin-dry-salted white shrimp } \\
\text { (Litopenaeus vannamel) by the storage } \\
\text { temperature }\left({ }^{\circ} \mathrm{C}\right) \text { kept in PA (vaccum) }\end{array}$} \\
\hline & $4 \pm 2^{\circ} \mathrm{C}$ & $28 \pm 2^{\circ} \mathrm{C}$ & $4 \pm 2^{\circ} \mathrm{C}$ & $28 \pm 2^{\circ} \mathrm{C}$ \\
\hline 0 & $8.90 \pm 0.00^{a}$ & $8.90 \pm 0.00^{a}$ & $8.90 \pm 0.00 a$ & $8.90 \pm 0.00 a$ \\
\hline 3 & $8.66 \pm 0.02^{\mathrm{ab}}$ & $8.48 \pm 0.03^{a b}$ & $8.85 \pm 0.01 \mathrm{ab}$ & $8.75 \pm 0.01 a b$ \\
\hline 6 & $8.48 \pm 0.02^{b}$ & $8.33 \pm 0.01^{b}$ & $8.71 \pm 0.03 b$ & $8.50 \pm 0.03 b$ \\
\hline 9 & $8.35 \pm 0.01 b^{c}$ & $8.17 \pm 0.03^{b c}$ & $8.63 \pm 0.02 b c$ & $8.21 \pm 0.01 b c$ \\
\hline 12 & $7.95 \pm 0.00^{c}$ & $7.45 \pm 0.01^{c}$ & $8.50 \pm 0.01 c$ & $7.89 \pm 0.02 c$ \\
\hline
\end{tabular}

Note: the values were expressed as the mean of three repetitions; the same characters (denoted above), the difference between them was not significant $(\alpha=5 \%)$.

Drying decreases the water activity, so maintaing food stability by eliminating microorganism and enzymatic reactions without deterioration. The spoilage of shrimp is particularly due to bacteria. Styrofoam was seen to be the most effective packaging material for both processed whole and peeled dried shrimp ${ }^{21}$. Nutrition and stability of dry smoked and gamma irradiated shrimps were studied. After 4 months of preservation, there was a significant enhancing in protein and ash contents ${ }^{12}$.

\section{CONCLUSION}

White shrimp is an excellent source of dietary protein. The principle of drying is to reduce moisture to maximum levels to prevent microorganism growth and also slow down enzymatic/ biological reactions that cause food deterioration. Artificial color presented on dried shrimp in the market was rejected. We were trying to produce curcumin-dry-salted white shrimp come from turmeric as an alternative. This research aimed to study the possibility to produce dried shrimp by mixing with turmeric and salt. Results revealed that $0.75 \%$ of salt with addition of $0.5 \%$ of curcumin during soaking 15 minutes; steaming at $110^{\circ} \mathrm{C}$ in 30 seconds; drying at $50^{\circ} \mathrm{C}$ in $4.5 \mathrm{~h}$, the curcumin-dry-salted white shrimp products had the good physicochemical, microbiological and sensory characteristics. By preserving under vacuum at $4^{\circ} \mathrm{C}$, the curcumin-dry-salted white shrimp could be maintained shelf-life for 12 months without any deterioration. Dried shrimp produced from turmeric and salt meet the quality criteria by Vietnamese authority agency. Dried shrimps are popular and widely acceptable.

\section{ACKNOWLEDGEMENT}

We acknowledge the resources and financial support for the study was provided by Nguyen Tat Thanh University, Vietnam.

\section{REFERENCES}

1. Oosterveer, P. Globalization and sustainable consumption of shrimp: Consumers and governance in the global space of flows. International Journal of Consumer Studies., 2006, 30, 465-476.

2. Gunalan, B.;NinaTabitha, S.;Soundarapandian, $\mathrm{P}$; and Anand T. Nutritive value of cultured white leg shrimp Litopenaeus vannamei. International Journal of Fisheries and Aquaculture., 2013, 5, 166-171.

3. Syama Daya, J.; Ponniah, A. G.; Imran Khan, H.; Madhu Babu, E. P.; Ambasankar, K.; and Kumarguru Vasagam, K. P. Shrimps - a nutritional perspective. Current Science., 2013, 104, 1487-1491. 
4. Lin, T.M; Durance, T. D; and Scaman, C. H. Physical and sensory properties of vacuum microwave dehydrated shrimp. Journal of Aquatic Food Product Technology., 1999, 8, 41-53.

5. Prachayawarakorn, S.; Soponronnarit, S.; Wetchacama, S.; and Jaisut, D. Desorption isotherms and drying characteristics of shrimp in superheated steam and hot air. Drying Technology., 2002, 20, 669-684.

6. Rungtip Tapaneyasin; Sakamon Devahastin; Ampawan Tansakul. Drying methods and quality of shrimp dried in a jet-spouted bed dryer. Journal of Food Process Engineering., 2005, 28, 35-52.

7. Mosarrat Nabila Nahid; Gulshan Ara Latifa; Shubhash Chandra Chakraborty; Farzana Binte Farid; Mohajira Begum. Effect of Salt and Turmeric treated smoke-drying method on the sensory, proximate, chemical and microbial quality of $G$. chapra, X. cancila and M. pancalus fish. International Journal of Advanced Education and Research., 2015, 2, 20-25.

8. Akonor, P. T.; Ofori, H.; Dziedzoave, N. T.; and Kortei, N. K. Drying characteristics and physical and nutritional properties of shrimp meat as affected by different traditional drying techniques. Hindawi Publishing Corporation International Journal of Food Science., 2016, 1, 1-5.

9. Prabhu, N.M.; Rajasekar, P.; Nisha, R.G.; Yasminebegam, A.A.; Kannapiran, E.; Manikandan, R. Effect of turmeric on shrimp (Penaeus semisulcatus) shelf life extension in chilled storage conditions. Iranian Journal of Fisheries Sciences., 2016, 15, 39-52.

10. Taniya Alex. Effect of spices and herb for enhancing microbial quality and shelf life of dried Indian oil sardine (Sardinella longiceps) fish during storage at room temperature. IOSR Journal of Environmental Science, Toxicology and Food Technology., 2016, 10, 44-51.

11. P Thanthong, $Y$ Mustafa and D Ngamrungroj. Production of dried shrimp mixed with turmeric and salt by spouted bed technique enter the rectangular chamber. Journal of Physics: Conf. Series., 2017, 901, 012036.

12. Felicia Akuamoa; George Tawia Odamtten and Nii Korley Kortei. Nutritional and shelf-life studies of dry smoked and gamma irradiated shrimps (Penaeus notialis) from three different water sources in Ghana. Cogent Food \& Agriculture., 2018, 4, 1505803.

13. Rostini, I.; and Pratama, R. I. Effect of steaming on physical and chemical characteristics white shrimp (Litopenaeus vannamei) from Indramayu Waters. IOP Conf. Series: Earth and Environmental Science., 2018, 176, 1-9.

14. Sivertsvik, M.; Jeksrud, W.K. and Rosnes, J.T. A review of modified atmosphere packaging of fish and fishery products - significance of microbial growth activities and safety. International Journal of Food Science and Technology., 2002, 37, 107-127.

15. Donsi, G.; Ferrari, G.; and Matteo, P. Di. Utilization of combined processes in freezedrying of shrimps. Food and Bioproducts Processing: Transactions of the Institution of Chemical Engineers., 2001, 79, 152-159.

16. Niamnuy, C.; Devahastin, S. and Soponronnarit $\mathrm{S}$. Effects of process parameters on quality changes of shrimp during drying in a jet-spouted bed dryer. Journal of Food Science., 2007, 72, 553-563.

17. Zhang, G.; Arason, S. and Arnason, S.V.Physical and sensory ' properties of heat pump dried shrimp (Pandalus borealis). Transactions of the Chinese Society of Agricultural Engineering., 2008, 24, 235-239.

18. Nishant Thakur; Raman Bansal and Manish Goswami. Historical perview of turmeric in Indian society and potential of the natural gums in the modern day formulations. European Journal of Pharmaceutical and Medical Research., 2018, 5, 208-212.

19. AOAC. Official Methods of Analysis. $18^{\text {th }} \mathrm{ed}$. Association of Official Analytical Chemists, Maryland, USA, 2000.

20. Sriket, P.; Benjakul, S.; Visessanguan, W.; and Kijroongrojana, K. Comparative studies on chemical composition and thermal properties of black tiger shrimp (Penaeus monodon) and white shrimp (Penaeus vannamei) meats. Food Chemistry 2007, 103, 1199-1207. 
21. Jayasinghe, P. S; Jayasinghe, J. M; and Galappaththi, C. P. Influence of different processing methods on quality and shelf life of dried shrimp. Sri Lanka Journal Aquatic Science., 2006, 11, 85-91.

22. Namsanguan, $\mathrm{Y}$; Tichangton, S; Tia, W; Soponronnarit, S; and Devahastin, $S$. Simulation of a mixed air and superheated steam drying system. Drying Technology., 2005, 23, 25-248.

23. Manjarekar, R.G. and Mohod, A.G. Economic evaluation of solar tunnel dryer for drying peeled prawns. International Journal of Agricultural Engineering., 2010, 3, 68-72.
24. Namsanguan Y.; Tia W.; Devahastin, S.; and Soponronnarit, S. Drying kinetics and quality of shrimp undergoing different two-stage drying processes. Drying Technology., 2004, 22, 759-778.

25. Devahastin, S.; Tapaneyasin, R.; and Tansakul, A. Hydrodynamic behavior of a jet spouted bed of shrimp. Journal of Food Engineering., 2006, 74, 345-351.

26. Guochen, Z.; Arason, S.; and Arnason, S. A. Dehydration property of shrimp (Pandalus borealis) undergoing heat-pump drying process. International Journal Agriculture \& Biology Engineering., 2009, 2, 92-97. 